\title{
Undervisning $i$ en sammansatt textvärld: En intervjustudie med svenska och norska gymnasielärare om undervisning i kritisk läsning och kritisk värdering av källinformation
}

\author{
Eva Wennås Brante` and Elisabeth Stang Lund \\ Department of Education, University of Oslo, Oslo, Norway
}

\begin{abstract}
Via Internet har elever möjlighet att söka information om de flesta ämnen, samtidigt har ansvaret för att bedöma tillförlitligheten av den funna informationen i större grad hamnat hos eleven. Utvärdering av källinformation och förståelse av innehåll i dokument är växelvis beroende av varandra och elever behöver uppmärksamma samt använda tillgänglig källinformation om dokument vid läsning och tolkning av innehåll för att konstruera en integrerad mental modell över flera dokument. I denna studie har det via intervjuer undersökts hur gymnasielärare i Norge och Sverige förhåller sig till undervisning i källhantering och kritiskt granskande av källor. Dessutom undersöktes ifall de två grupperna av lärare resonerade likartat eller ej, då de nationella styrdokumenten skiljer sig åt. Intervjuerna har analyserats tematiskt. Två huvudteman identifierades. De norska lärarna reflekterar över hur kritiskt läsande och kritisk källhantering passar eller inte passar in i norskämnet, medan de svenska lärarna talar om att uppfylla kunskapskrav från läroplanerna gällande dessa företeelser. Att medvetet använda källinformation för att predicera, granska och utvärdera innehåll vid läsning och därmed skapa en integrerad mental modell över flera dokument förekommer sparsamt. Den senare strategin bör främjas i ett informationssamhälle där motstridiga texter av skiftande kvalitet och relevans publiceras på Internet.
\end{abstract}

\section{Nyckelord: Kritiskt läsande; kritisk källhantering; källinformation; intervjuer; gymnasieskola}

\begin{abstract}
In a modern textual world, the internet provides student with access to a wide range of information resources. Meanwhile, it is often up to the individual student to evaluate the quality of documents found on the internet. Reading, understanding and evaluating content information is dependent on attending to and evaluating source information. Therefore, students need to use documents' source information, along with documents' content, to construct an integrated mental model based on multiple document reading. Based on this, we set out to interview Norwegian and Swedish upper secondary school teachers. The topic was how they approached teaching critical reading and sourcing
\end{abstract}

*Correspondence to: Eva Wennås Brante, Department of Education, University of Oslo, P.O.Box 1092, Blindern, 0317 Oslo, Norway. E-mail: e.w.brante@iped.uio.no

(C)2017 Eva Wennås Brante and Elisabeth Stang Lund. This is an Open Access article distributed under the terms of the Creative Commons Attribution 4.0 International License (http://creativecommons.org/licenses/by/4.0/), allowing third parties to copy and redistribute the material in any medium or format and to remix, transform, and build upon the material for any purpose, even commercially, provided the original work is properly cited and states its license. Citation: E. W. Brante and E.S. Lund. "Undervisning $i$ en sammansatt textvärld: En intervjustudie med svenska och norska gymnasielärare om undervisning $i$ kritisk läsning och kritisk värdering av källinformation"Nordic fournal of Literacy Research, 


\section{E. W. Brante and E. S. Lund}

skills in the classroom. Furthermore, we examined whether the Norwegian and Swedish teachers approached the topic of critical reading and sourcing differently. If so, could these differences be connected to differences in the national steering documents? Interviews were analyzed thematically. Two main themes were identified. Norwegian teachers talked about whether or not teaching critical reading and sourcing skills was in line with the curricula, The Swedish teachers, on the other hand, were concerned with proficiency requirements and exam results. Sourcing skills can be seen as crucial in a complex information society, where the quality of information provided varies enormously.

Keywords: Critical reading; evaluation; source information; interviews; upper secondary teachers

Received: January, 2017; Accepted: June, 2017; Published: September, 2017

\section{Introduktion}

Att kritiskt granska källor och på så vis vara en kritisk läsare är långt ifrån en ny företeelse eller ett nytt krav på elever. Vad som kan sägas vara nytt idag är att läsning kan ske via en rad olika medier (Leu, Forzani et al., 2015) samt att elever vid online-läsning kan röra sig fram och tillbaka mellan dokument, det vill säga att läsningen i större grad sker på ett dynamiskt än på ett linjärt vis (Kress, 2014). Dessutom, när läsning sker online är det högst troligt att elever stöter på motstridig information, då olika intressegrupper kan publicera dokument i samma sakfråga men från olika perspektiv. Det kräver att elever utvärderar det de läser, till exempel genom att vara uppmärksam på vem eller vilka som har publicerat det specifika dokumentet, när det är publicerat och med vilken intention. En text blir på så vis mer än en lingvistisk konstruktion (Britt \& Rout, 2012), då texter har flera aspekter än språkliga att ta fasta på, som till exempel intentionen någon har haft med att skriva den. Utvärdering av källinformationen och förståelse av innehållet i dokumentet är ömsesidigt beroende av varandra (Britt, Richter \& Rouet, 2014). Den som läser bör ju förstå ett innehåll för att kunna utvärdera det, och genom utvärdering så får läsaren stöd i att övervaka sin egen förståelse samt att integrera ny kunskap i en iterativ process (Barzilai, Tzadok, \& Eshet-Alkalai, 2015; Britt et al., 2014; Goldman, Braasch, Wiley, Graesser, \& Brodowinska, 2012; Wiley et al., 2009). Att kritiskt granska och utvärdera information före, under och efter läsning för att främja läsförståelsen av multipla dokument är också den betydelse vi tillskriver begreppet kritiskt läsande i denna artikel.

OECD (2013) benämner kompetenser som att kritiskt granska, utvärdera och integrera information som exempel på väl utvecklad literacy; en syn på literacy som flera länder har införlivat i sina nationella läroplaner, dels på en övergripande nivå och dels specificerat i ämnen som till exempel samhällskunskap, historia och modersmålsundervisning. Formuleringar i läroplaner rör dock mål med undervisningen, inte vägen fram till målen (Goldman et al., 2016); det är lärare som sedan transformerar målen till undervisning. Lärare förväntas, av skolledning och myndigheter, att känna till styrdokumenten samt att aktivt använda dem vid planering i undervisning. Det gör det relevant att undersöka hur lärare uppfattar skrivningar i läroplaner som berör att kritiskt granska och utvärdera information, speciellt som forskning visar att 
uppmärksamhet av källinformation vid läsning av flera dokument är av avgörande betydelse för läsförståelsen (e.g. Britt, Richter \& Rouet, 2014; Goldman et al., 2016). Att ta källinformation i beaktande vid läsning har dock tillmätts olika vikt inom olika discipliner. Inom historieämnet, till exempel, har det av tradition uppfattats som en central kompetens, på engelska benämnd sourcing (Wineburg, 1991) medan det inom modersmålsundervisning och läsning av skönlitteratur tidigare inte alls haft samma ställning, utan snarare setts som överflödigt (Goldman et al., 2016).Vi fann det därför speciellt intressant att undersöka hur lärare som undervisar i modersmål uppfattar intentionerna i läroplanerna samt om den väl utvecklade literacy som OECD beskrivit (2013) och som speglas i läroplaner uppfattades som självklar för modersmålslärare att införliva i sin undervisning. Utifrån detta formulerades forskningsfrågan: Hur förhåller sig lärare till styrdokumentens intentioner när det gäller kritisk läsning och kritisk värdering av källinformation? En aspekt av lärares förhållning till styrdokumentens intentioner berör även, menar vi, ifall lärare undervisar i kritisk värdering av källinformation på ett sätt som främjar läsförståelsen av multipla dokument. För att besvara vår forskningsfråga har ett antal gymnasielärare (företrädesvis modersmålslärare) intervjuats. Intervjuerna fungerade också som en förberedelse till en intervention riktad mot norska gymnasielevers förmåga att kritiskt läsa samt utvärdera källinformation (finansierad av Norska vetenskapsrådet, bidrag nr 237981/H20).

OECD (2013) pekar ut vad som definiererar en väl utvecklad literacy-nivå oavsett nation. Emellertid är det inte säkert att undervisning i att kritiskt läsa samt utvärdera källinformation försiggår på ett likartat vis i olika nationer. Det väckte vårt intresse för att undersöka ifall kompetenser som att kritiskt granska, utvärdera och integrera information uppfattades liknande eller ej i två grannländer, vilka påminner om varandra i statsskick och kultur. Intervjuerna av norska lärare följdes således upp med intervjuer av svenska gymnasielärare för att nå en fördjupad förståelse av hur lärare från två grannländer förhåller sig till undervisning i kritisk läsning och källvärdering.

\section{Läsning i informationssamhället}

Att läsa i dag inbegriper ofta att kryssläsa mellan flera än ett dokument. På grund av mångfalden av informationskällor har det från flera håll lyfts fram nödvändigheten av att $\mathrm{i}$ en sådan läsprocess även uppmärksamma vem som är författaren och dens intentioner med sin text (Britt \& Rouet, 2012; Leu, Forzani et al., 2015) för att på så vis underlätta tolkning och integrering av innehållet i dokumenten. Britt och kollegor (Britt \& Rouet, 2012; Perfetti, Rouet \& Britt, 1999) har i The Documents Model beskrivit hur en läsare kan skapa läsförståelse vid läsning av flera dokument. De har utgått från Kintsch modell (Kintsch, 1998) av hur läsförståelse skapas vid läsning av ett dokument. Enligt Kintsch (1998) konstruerar en läsare förståelse på tre nivåer; på ordnivå, på meningsnivå samt den nivå som Kintsch rubricerade som en situationsmodell av det lästa. Den sistnämnda konstrueras genom att lägga till egna erfarenheter 


\section{E. W. Brante and E. S. Lund}

och omvärldskunskap till meningsnivån. För att en läsare sedan ska erhålla läsförståelse över flera dokument, behövs enligt Britt och kollegor, ytterligare två lager av mentala strukturer. Läsaren bör helst skapa en integrerad mental modell, vilket är en representation av hur innehållet i dokumenten relaterar till varandra (Britt \& Rouet, 2012; Perfetti, Rouet \& Britt, 1999). Därutöver bör läsaren skapa en intertext modell, i vilken läsaren använder sig av olika typer av källinformation för att organisera innehållet (Britt, Richter, \& Rouet, 2014). Genom att notera avsändaren till ett dokument kan läsare mentalt representera vem som sa vad, hur olika källor förhåller sig till varandra samt hur källinformationen förhåller sig till ett innehåll, det vill säga genom att uppmärksamma med vilket intresse eller i vilken genre ett dokument är skrivet. Med andra ord, samtidigt som läsaren tar del av innehållet så bör läsaren uppmärksamma källinformation om dokumentet (Britt \& Rouet, 2012). Först då kan läsaren integrera informationsbitarna till en komplett 'documents model' (Britt, Rouet \& Braasch, 2013).

Online-läsning är, jämfört med traditionell läsning, särskilt nära förknippat med att söka svar på frågor (Leu et al., 2013). Leu och kollegor (2013) har i ramverket The New Literacies beskrivit olika typer av läsaktiviteter som är i funktion vid online-läsning: läsa för att identifiera viktiga frågor; för att lokalisera information; för att kritiskt utvärdera information; för att syntetisera information och för att kommunicera det lästa. Även i The New Literacies poängteras vikten av att läsaren engagerar "higher-level thinking skills such as critical evaluation of source material" (Leu, Zawilinski, Forzani, \& Timbrell, 2015, s. 346). Vad det innebär mera konkret att kritiskt utvärdera information har konceptualiserats av Kim och Hannafin (2016), vilka delat upp utvärdering i fyra olika processer. Processerna sker optimalt och iterativt då en läsare försöker lösa en uppgift baserad på en frågeställning genom att söka information på Internet. Utvärderingen av information kan ske i förväg, som en form av predicering över hur och var det kan vara möjligt att hitta information (predictive evaluation); den kan ske utifrån den faktiska källinformationen, som vem som är författare och när informationen är publicerad (intrinsic evaluation); den kan ske i relation till annan information, som en kontrasterande jämförelse och en undersökning av argumentens evidens (extrinsic evaluation); och slutligen, den kan ske som en reflekterande utvärdering (reflective evaluation), där läsaren ställer sig själv frågor som "har jag starka argument" eller "har jag motargument som jag kan diskutera" (Kim \& Hannafin, 2016). Den kritiska utvärderingen kan alltså ske med olika syften, som avlöser varandra.

Det kan framstå som självklart och enkelt att elever ska uppmärksamma källinformation vid läsning av flera dokument, men tidigare studier visar att det finns brister i hur elever uppmärksammar källinformation samt i deras förmåga att använda sig av den vid läsning av ett eller flera dokument. Exempelvis, i en studie där gymnasieelever fick "tänka-högt" kring hur de går till väga vid sökning av information, visade det sig att de främst utvärderade innehållets relevans för uppgiften och bortsåg från avsändaren (Kiili, Laurinen, \& Marttunen, 2008). I en senare studie av Bråten, Strømsø och Andreassen (2016) fann författarna att när universitetsstudenter 
( $n=259)$ skulle fatta beslut i hälsorelaterade frågor utifrån läsning av multipla dokument så undlät de att utvärdera innehållslig information med hjälp av tillgänglig källinformation och förlitade sig istället på personliga erfarenheter. En faktor som positivt förutspår läsares förmåga att knyta källinformation till innehåll, är i vilken utsträckning läsare minns att det förekommer motsägelser i innehållet de läste (Stang Lund, Bråten, Brante \& Strømsø, 2017).

Interventionsstudier har visat att när elever i 16-17 årsåldern väl tar hänsyn till källinformation under läsning så främjar det deras förståelse av multipla texter (Braasch, Bråten, Strømsø, Anmarkrud, \& Ferguson, 2013; Mason, Junyent, \& Tornatora, 2014). Det har också visat sig att en så pass enkel strategi som att uppmana elever att skriva ner källan till informationen har betydelse för elevers möjligheter att bättre utvärdera trovärdigheten av informationen (Kammerer, Maier, \& Stahl, 2016). Att utvärdera trovärdigheten av information är ett steg mot skapandet av en mental modell över flera dokument och därmed mot en djupare läsförståelse.

Som framgår av resultaten från de här redovisade studierna finns det utrymme för att utveckla elevers kompetens inom området kritisk värdering av källinformation.

Studierna som nämns ovan har genomförts vid ett eller ett par tillfällen och varit ledda av forskare. Lärarens roll i undervisningen bör tydligare lyftas fram, då lärare har ett stort ansvar för elevers utbildning. Vi menar att det är av vikt att undersöka lärares uppfattningar kring läroplanernas formuleringar rörande kritisk värdering av källinformation och kritiskt läsande, eftersom det är lärare som planerar och genomför undervisningssekvenser tänkta att utveckla den kompetensen hos eleverna. Innan vi redovisar metod och resultat ger vi en kort redogörelse för Sverige och Norges läroplaner för gymnasieskolan, då de skiljer sig åt på några väsentliga punkter.

\section{Läroplaner för gymnasieskolan i Sverige och Norge}

Den gällande läroplanen för svensk gymnasieskola blev implementerad 2011. En del av läroplanen för gymnasieskolan består av ämnesplaner för de gymnasiegemensamma ämnena. Varje ämnes centrala innehåll och syfte beskrivs inledningsvis, därefter följer ämnets kursplaner. I kursplanerna preciseras betygskraven via graderade betygskriterier riktade mot olika förmågor (Skolverket, 2015). Till exempel, ett kriterie är riktat mot läsförmåga och för att få högsta betyget (A) i den första kursen i svenska ska eleven kunna "läsa, reflektera över och göra sammanfattningar av texter samt skriva egna texter som lyfter fram huvudtanken i det lästa och ger nya relevanta perspektiv" (Skolverket, 2015, s. 167). För betyget E (lägsta betyget) beskrivs förmågan istället som att "Eleven kan läsa, reflektera över och göra enkla sammanfattningar av texter samt skriva egna texter som anknyter till det lästa“" (Skolverket, 2015, s. 167). Eleverna måste ha klarat av allt som står på ett betygssteg för att kunna nå ett högre betygssteg.

I Sverige ges nationella prov i modersmål i första och sista årskursen på gymnasiet för alla program utom yrkesprogrammen - där genomförs de endast i första årskursen. Proven är främst summativa och ska fungera som en avstämningspunkt 


\section{E. W. Brante and E. S. Lund}

mot slutet av ett läsår. Proven kan även användas formativt, både vad gäller elevens lärande och utveckling av undervisningen (Ericksson \& Gustafsson, 2014). Bedömningsanvisningar till de nationella proven administreras centralt och det är undervisande lärare som genomför bedömningen. Den skriftliga delen är tydligt riktad mot att skriva argumenterande texter.

Den nuvarande läroplanen för den norska gymnasieskolan är en del av Kunskapslöftet 2006 (LK06, 2006). I läroplanen finns kompetensmål för varje ämne och varje årskurs på gymnasiet. Betyg sätts på en sexgradig skala efter hur väl eleven har uppfyllt kompetensmålen. Betyget 1 innebär att eleven har väldigt låg kompetens i ämnet och betyget 6 innebär förträfflig kompetens. Underlaget för ett visst betyg i ett ämne är samtliga kompetensmål för det ämnet, det vill säga att lärarna bör se kompetensmålen som en helhet. Kompetensmålen ska också läsas i ljuset av beskrivningen av ämnets syfte, som återfinns i läroplanen. Ett kompetensmål i norska i första årskursen är till exempel att kunna "tolke og vurdere sammenhengen mellom innhold, form og formål i sammensatte tekster" (LK06, 2006). I norsk läroplan preciseras således inte vad varje betygssteg betyder i varje delmoment. I tillägg till kompetensmålen anges i läroplanen fem grundläggande färdigheter, vilka utgör förutsättningar för lärande och utveckling (LK06, 2006). De fem färdigheterna är att läsa, att räkna, att skriva, att tala samt att inneha digital kompetens. Det beskrivs årskurs för årskurs och ämne för ämne vad som utgör färdigheten. Färdigheterna examineras inte, utan utgör en grundstomme i undervisningen.

Mot slutet av gymnasieutbildningen ges skriftlig och muntlig examen i norska (och minst ett annat ämne). Examensskrivningen i norska bedöms av externa sensorer utifrån givna kriterier som specificerar mera i detalj vilken kompetens eleven ska ha för de olika betygsstegen. Dessa kriterier finns även tillgängliga för lärare.

De skillnader mellan svensk och norsk läroplan för gymnasieskolan som främst är relevanta för den här artikeln är skillnaden i hur betygskraven preciseras samt i hur elever testas nationellt i modersmålet - via nationella prov i första och sista årkursen i svensk gymnasieskola eller via examen mot slutet av gymnasietiden i norsk gymnasieskola.

\section{Metod}

Intervjuerna redovisade $\mathrm{i}$ den här artikeln ramades in av citat från styrdokument för gymnasieskolan (se Appendix A). Valet av att utgå från styrdokumenten grundar vi i att det ingår i lärares tjänsteutövning att organisera sin undervisning utifrån skrivningar i styrdokumenten. Dessutom hade vi analyserat fyra vanligt förekommande läromedel i norska för gymnasieskolan, och även om de skilde sig delvis åt så korresponderade innehållet tydligt med läroplanens intentioner. ${ }^{1}$ Lärarna fick vid intervjutillfället läsa två korta utdrag som berörde fokus för intervjuerna (kritisk värdering av källinformation och kritisk läsning). Vi valde medvetet citat från de mera allmänna delarna av

\footnotetext{
${ }^{1}$ Förste författare var redan bekant med läromedel i en svensk kontext
} 
läroplanerna, alltså inte specifika betygskriterier, då vi ville underlätta för lärarna att tala kring kompetenserna och undvika att de skulle redovisa hur de uppnått konkreta betygsmål. För att kunna ta del av lärares uppfattningar och åsikter valde vi intervjuer som metod (Kvale \&Brinkmann, 2015). Vi eftersökte också lärare från olika skolor och olika städer för att få en spridning på deltagarna. Observationer av undervisningen kunde ha bidragit med värdefull information. Vi valde dock bort observationer då det var omöjligt att i förväg veta ifall lärarna spontant skulle undervisa om kritisk värdering av källinformation vid ett speciellt observationstillfälle.

\section{Deltagare}

Vi sökte lärare som arbetade på gymnasiet och som främst undervisade i norska i Norge eller i svenska i Sverige men även i samhällskunskap/historia, då de ämnena har kritiskt läsande och kritiskt granskande av källor angivna som kunskapskrav eller kompetensmål. Personliga faktorer som ålder och kön lämnade vi utanför frågeställningen i den här studien. För att få kontakt med lärare som stämde in på inkluderingskriterierna så sände vi ut förfrågningar via e-post till skolor, rektorer samt kollegor vid lärarutbildning och universitet. Vi publicerade också en annons på UV-fakultetets (vid Oslo Universitet) Facebook-sida. Via dessa olika kanaler fick vi kontakt med arton lärare som var intresserade av att bli intervjuade. Sjutton av lärarna som anmälde sig till intervjustudien undervisade i något av ländernas respektive modersmål. De flesta av lärarna undervisade även i ett annat ämne, till exempel historia, samhälllskunskap eller engelska. En norsk lärare undervisade enbart i samhällskunskap. Sammantaget kom lärararna från elva olika skolor och sju olika städer (se tabell 1 för en översikt).

\section{Material}

Vi utgick från tidigare redovisad forskning om vad som utgör elevers svårigheter rörande kritisk värdering av källinformation vid formulerandet av intervjufrågor

Tabell 1. Översikt över deltagare

\begin{tabular}{llll}
\hline Land & Stad & Skola & Lärare \\
\hline Norge & A & Nr 1 & N1 \\
& & Nr 2 & N2 \\
& B & Nr 3 & N3 \\
& & Nr 4 & N4; N5; N6 \\
Sverige & C & Nr 5 & N7; N8; N9 \\
& D & Nr 6 & S1 \\
& E & Nr 7 8 & S2; S3; S4; S5 \\
& F & Nr 9 & S6 \\
& & Nr 10 & Sr 11 \\
& & Gr & S9
\end{tabular}




\section{E. W. Brante and E. S. Lund}

(se Appendix B). Frågorna hade en öppen karaktär som till exempel "Vilka utmaningar ser du med att arbeta med de här frågorna?" De flesta frågor följdes upp med att vi bad om konkreta exempel eller en beskrivning av en specifik situation i relation till frågan. Vi ville därmed öka möjligheten att lärarna i sina svar gav uttryck för hur deras undervisning genomfördes.

Intervjuerna genomfördes på tidpunkter som passade lärarna. Tolv av lärarna önskade att bli intervjuade på sin arbetsplats, tre valde att komma till förste författarens arbetsplats i Norge eller Sverige och tre önskade att bli intervjuade via telefon. De som blev intervjuade via telefon befann sig i sina hem vid tidpunkten för intervjun. Genomsnittstiden för intervjuerna var knappt 33 minuter. Samtliga intervjuer genomfördes av första författaren till denna artikel. Alla intervjuer spelades in, dock misslyckades inspelningen av en av de norska lärarna (N9). Den intervjun är därför inte med $i$ analysen.

\section{Analys av intervjudata}

Vi använde oss av ett induktivt tematiskt förfarande (Braun \& Clarke, 2006; Hayes, 2000) vid analys av intervjusvaren. Efter transkribering översattes de norska intervjusvaren till svenska för att få en enhetlig språkdräkt i artikeln. Därefter startade vi med upprepade genomläsningar av samtliga intervjuer för att bekanta oss med materialet, och sedan vidtog kategorisering av uttalandena. I nästa steg grupperade och sorterade vi kategorierna för att kunna identifiera teman, alltså mera övergripande beskrivningar av kluster av kategorier (Braun \& Clarke, 2006). Braun och Clarke beskriver analysförfarandet som ett sätt att "find repeated patterns of meaning" (2006, p. 86).Vårt forskningsintresse rörde framförallt lärarnas undervisning i kritisk värdering av källinformation samt i vilken utsträckning undervisningen främjade läsförståelse av multipla dokument som det beskrivs i The Document Model (Britt \& Rouet, 2012) och ifall lärarnas syn på vikten av att undervisa om kritisk värdering av källinformation låg i linje med ett sådant synsätt. Det var först när vi kom till steget identifiera teman som det blev tydligt att intervjuerna skulle analyseras nationsvis istället för att ses som ett material. Detta betyder inte att alla lärare i varje nation hade exakt samstämmiga svar, men genom den induktiva analysen så identifierade vi tematiska skillnader. Trots heterogeniteten bland deltagarna från varje land (olika skolor, olika åldrar och med olika lång arbetserfarenhet) så utkristalliserades tydliga tematiska skillnader mellan de två länderna.

Som redovisats tidigare blev lärarna vid intervjusituationen presenterade för citat från sina respektive nationers läroplaner. Efter kategoriseringen av yttranden från intervjuerna fann vi att styrdokumentens föreskrifter, vilka delvis skilde sig åt mellan länderna, speglades i lärarnas hållning och inställning till kritiskt granskande av källor. Det ledde till att de teman vi identifierat i stort sett särade på lärarna från de två olika länderna. Intervjuerna berör visserligen samma fenomen, kritiskt läsande och kritisk värdering av källinformation, men i och med att intervjuerna hade som utgångspunkt olika citat från de respektive nationella läroplanerna blev det tydligt att 
kontexten som lärararna verkar inom spelar en stor roll. De två temana representerar alltså lärarsvaren nationsvis.

\section{Resultat}

I resultaten redovisar vi, via två teman, hur lärararna förhåller sig till styrdokumentens intentioner när det gäller kritisk läsning och kritisk värdering av källinformation samt i fall det är synligt att lärarna undervisar i kritisk värdering av källinformation på ett sätt som främjar läsförståelsen av multipla dokument? De citat som återges har anonymiserats och lärarna har kodats med $\mathrm{N}$ eller $\mathrm{S}$ beroende på nationstillhörighet, samt en siffra (se tabell 1).

De svenska lärarna kopplade i stor utsträckning läroplanens citat till betygskriterier både i svenskkurser och för de nationella proven, det vill säga att de hade olika förordningar och föreskrifter i fokus, medan de norska lärarna utgick från sin uppfattning om ämnet i sig när de talade om hur de upplevde att citaten passade in på deras bild av norskämnet. Dessa två teman har vi benämnt Mål i fokus samt Ämnet i fokus (se tabell 2 för en översikt). De beskrivs nedan ett åt gången.

Tabell 2. Beskrivning av huvudteman med exempelcitat

\begin{tabular}{|c|c|c|}
\hline & Mål i fokus & Ämnet i fokus \\
\hline $\begin{array}{l}\text { Hur citat från läroplanen tas } \\
\text { emot samt hur intentioner från } \\
\text { läroplanen nämns }\end{array}$ & Som krav som lärarna ska uppfylla & $\begin{array}{l}\text { Som en del av innehållet i } \\
\text { norskämnet }\end{array}$ \\
\hline Strategier som tillämpas & $\begin{array}{l}\text { Erbjuda träningstillfällen } \\
\text { Kontrollera betygskriterier } \\
\text { Preparera för nationella prov }\end{array}$ & $\begin{array}{l}\text { Närläsa skönlitterära texter } \\
\text { Träna på retoriska analyser } \\
\text { Medvetandegöra elever }\end{array}$ \\
\hline Exempel - citat & $\begin{array}{l}\text { ”ändå tränar vi det redan, eller jag } \\
\text { gör det redan från ettan och det ska } \\
\text { vi nog alla göra, för det är faktiskt } \\
\text { det GY11’s kurser i stort, som är } \\
\text { teoretiska, ska gå ut på, jag kan inte } \\
\text { längre låta eleverna, hur mycket de } \\
\text { än vill, skriva novell på svenskan, för } \\
\text { det är inte det de ska göra, de ska } \\
\text { träna sig för att skriva vetenskaplig } \\
\text { text”. S3 } \\
\text { "finns det med källhantering? Check, } \\
\text { ja, då har du D, är den infogad i stora } \\
\text { drag på ett korrekt sätt, ja då är det } \\
\text { nästa nivå och för högsta så är det } \\
\text { varierat, och fullständigt och korrekt } \\
\text { och, så det är ganska tydligt och inte } \\
\text { så svårt vid betygssättning” S9 }\end{array}$ & $\begin{array}{l}\text { "den här begreppsapparaten vi ger } \\
\text { dem i retorik, då, är något som } \\
\text { kan ge dem förmågan till att se, } \\
\text { alltså analysera på ett mera precist } \\
\text { sätt, och att en norsklärere kan } \\
\text { ge exempel på maktbruk eller, ja, } \\
\text { att man analysera en politikers tal } \\
\text { eller någonting, ett exempel då, så } \\
\text { man kan avtäcka det ena eller det } \\
\text { andra" N8 } \\
\text { "Vi går faktiskt igenom texter } \\
\text { ganska noga, tillsammans, det har } \\
\text { jag kommit fram till att det är det } \\
\text { bästa, ord för ord, ser på ordval } \\
\text { och så” N1 } \\
\text { "Värderingen i vårt ämne ligger i } \\
\text { det att kunna tänka abstrakt, att } \\
\text { toka texter" N3 }\end{array}$ \\
\hline
\end{tabular}




\section{E. W. Brante and E. S. Lund}

Mål i fokus

Betygskriterierna är starkt närvarande när de svenska intervjuade lärarna talar om sin undervisning i källhantering och värdering av källinformation, speciellt som kompetensen specificeras redan på den lägsta betygsnivån i den första svenskkursen. För att få det lägsta betyget ska eleven visa att den i sitt arbete med viss säkerhet värderar och granskar källor kritiskt, samt tillämpar grundläggande regler för citat- och referensteknik, och som S4 säger: "det är ju en del av det centrala innehållet och, ja, på kunskapskravsnivå så är det ju faktiskt redan för E.” Det finns på så vis ett indirekt krav att lärare ska införliva moment med källhantering och kritiskt granskande redan från början i gymnasiet och lägga upp sin undervisning så att det ska bli möjligt för eleverna att visa sin kompetens i de olika betygskriterierna. Lärarna beskriver också elevens utveckling som pågående under hela gymnasieutbildningen och förklarar hur de lägger en grund i årskurs 1 som de sedan bygger vidare på via mer och mer komplicerade uppgifter, eller större och större krav på korrekt utförande. Det här kommer tydligt fram i intervjuerna, till exempel när lärare talar om hur de introducerar vikten av att stödja uttalanden med referenser redan från terminsstart "att ta med publikation och såna saker, och det började vi med i augusti, tror jag, på olika sätt att, att de skulle lära sig” (S7). Lärarna pekar också ut relationen mellan vad lärarna fokuserar i undervisning och kunskapskrav: "de måste ju ha mer än ett argument från flera olika källor de måste ha läst, och därav kommer det in att de kan granska information och söka, sammanställa, alltså, det är faktiskt saker som återkommer sen också i kunskapskraven" (S4).

De svenska lärarnas respons på citaten från läroplanen präglas av tal om krav; vad läroplanen och vad betygskriterierna föreskriver. De svenska lärarnas svar riktar också in sig mot konkreta strategier de tillämpar, hur de ska göra för att eleverna ska kunna inta en kritisk position, som till exempel att ställa frågor till texten eller att kontrollera källinformation som när en text är publicerad. Lärarna menar att det är deras ansvar att visa vägen för eleverna i den digitala världen eftersom den är så omfattande och svår att orientera sig i: "de lever i ett sånt mediabrus så att, jag tror att vi måste, vi måste ifrågasätta dem mycket mer med vad de väljer för något, faktiskt, de behöver verkligen hjälp med detta, så där tror jag vi behöver vara faktiskt, ta dem i handen och guida dem lite" (S9)

Samtidigt finns en insikt hos lärarna att de själva inte kan allt, att de också faller till korta vid värdering av källinformation. Flera av dem beskriver hur de använder sina misstag som exempel för eleverna, för att på så vis överbygga generationsklyftor. Lärarna känner inte heller helt igen sig i det digitala landskapet och anstränger sig för att hänga med, för att veta var eleverna rör sig på Internet så de kan diskutera källkritik i ett vidare perspektiv, till exempel i sociala medier: "jag tänker att många hänger ju på Instagram och Snapchat och så och bara kollar bilder, men det finns en avsändare med det, jag tror absolut att de är mogna för att förstå men de har inte blivit ställda inför det, ingen har kanske gjort dem uppmärksamma på det och det tror jag de kan bli då, förstå det” (S5). 
De intervjuade lärarna är medvetna om att i de nationella proven, som alla elever i årskurs 1 genomför i svenska/modersmål under våren, måste eleverna för att bli godkända använda källor och kunna uppge spårbara referenser. (I de nationella proven så skriver eleverna debattinlägg, argumenterande texter eller liknande, inte skönlitterära texter.) S6 förklarar vikten av att referera i skrivuppgiften "du får ju ut ett texthäfte och så ska de skriva, välja en av fyra uppgifter och så ska de referera till texten, och då ska de ju göra det korrekt”. Det poängteras också av lärarna, samt att det anges i kriterierna för bedöming som ett krav för godkänt: "men någon typ av källa måste du ha med, så att du kan visa på det då, för det är ändå en del av kriterierna då" (S5). Eftersom det i Sverige är undervisande lärare som bedömer de nationella proven blir det tydligt för lärarna vid bedömningen huruvida de har lyckats förmedla kunskaper rörande att stötta argument i källor samt att referera till källor. Samtidigt, vad det gäller de nationella proven så verkar lärarnas fokus där vara att eleverna skall uppge källor, i lägre grad att kritiskt värdera källinformation. Lärarna vet att om eleven inte uppger spårbara källor så får lärarna inte godkänna eleven, oavsett kvaliteten på den skrivna texten. Att kraven från styrdokumenten är närvarande i lärarnas uttalande kan ses både som ett stöd och ett hinder i undervisningspraktiken. De detaljerade betygskriterierna i de svenska ämnesplanerna verkar fungera som konkreta påminnelser för lärare om vad deras elever förväntas kunna efter avslutade kurser.

\section{Ämnet i fokus}

Vad läraren tänker kring vad som ingår eller inte ingår i ett ämne utgör lärares ämneskonception (Lindmark, 2013). De norska lärarnas respons på citaten rörande kritisk läsning och värdering av källinformation från styrdokumenten indikerar att de har en tydlig, om än personlig, uppfattning om hur dessa områden relateras till ämnet norska, eller norskfaget ${ }^{2}$. Den tydliga ämnesuppfattningen visar sig på två motsatta sätt rörande undervisning i kritisk värdering av källinformation - antingen menar lärarna att det inte ryms inom ämnets ramar "det var det som slog mig, de bör kunna, lära sig en del om såna saker först då, och då tänker jag kanske, att om man ska jobba mycket med det, så är man lite ute, kanske lite så att man är på väg ut ur läroplanen i norsk då” (N6) samt att kriterier som rättstavning eller hur väl en text behandlar ett tema " betyder nog mera för betyget än om de råkar ha en sån källförteckning på slutet" (N6) eller så menar lärarna att det är helt självklart att de sysslar med kritisk värdering av källinformation då de undervisar i norska: “det tänker jag att det kanske är något av det mest värdefulla i norskfaget är precis den här förmågan att, ja, den här begreppsapparaten vi ger dem i retorik, då, är något som kan ge dem förmågan till att se, alltså analysera på ett mera precist sätt” (N8). Inställningen att källkritik inte faller inom ämnet förs fram av endast en lärare. Den

\footnotetext{
${ }^{2}$ En av de intervjuade lärarna undervisar enbart i samhällskunskap. Han faller delvis utanför temat då han sjävklart inte har en identitet som norsklärare. Det som ändå förenar honom med övriga lärare är den starka ämnestillhörigheten.
} 


\section{E. W. Brante and E. S. Lund}

andra uppfattningen, där lärarna hävdar att värdering av den information som läses ständigt sker i norskundervisningen, är starkare förankrad: "det är ju realistiskt att eleverna kan bedöma och använda källor på ett medvetet vis, så det där medvetandegörandet är något jag gör alltid när vi läser texter, så snackar vi alltid om, för att göra dem medvetna om, det här är skrivet av någon som kanske har ett, en agenda" (N5). Temat Ämnet i fokus införlivar även vad som krävs för att kunna tillägna sig ämnet: "för att vara en del av liksom norsk text-gemenskap då så bör man ju kunna veta lite om olika texttyper, genrer som finns i norskfaget och då veta vilken typ av text det är, och då vet man också avsikten" (N5).

I linje med att ämnesuppfattningen är tydlig så talar lärarna också om norsklärarens uppgifter och identitet: "som norsklärare är det ju självklart i kärnområdet vad vi håller på med, tycker jag, att tänka kritiskt och tolka texter" (N3) och "det med att veta, att det finns flera sätt att läsa information på, att det finns flera källor till information, det tror jag är en primär uppgift vi norsklärare har” (N7). Det uttrycks tankar om att läraren kan väcka eleverna, få dem att reflektera, se saker ur flera perspektiv och göra medvetna val. På så vis menar lärarna att de ska ge eleverna insikter om värdet av kritiskt läsande.

Lärarna talar upprepade gånger om vikten av att eleven kan distansera sig från texten, se tendenser i texten, bedöma den utifrån annan information eller 'koppla på en örnblick' (N7), det vill säga se texten 'ovanifrån' och söka efter meningen med den. De norska lärarna talar med andra ord explicit om vad de vill att eleverna ska ha förstått. Det betonas att elevens egen kapacitet har betydelse. Eleverna, särskilt de duktigaste, förväntas klara av att kritiskt värdera källinformation och att använda källor i skrivuppgifter. Lärarna poängterar att det är olika svårt för olika elever att tillägna sig förmågan att kritiskt granska källinformation "självklart är det så att de svagaste inte får tag på det att vara kritisk mot källor, alltid, annat än vilka källor som det är ok att använda och vilka de inte får använda” (N8).

Sammanfattningsvis menar vi att frånvaron av detaljstyrning via betygskriterierna öppnar för att lärarna kan utforma sin undervisning på skilda vis och de verkar känna en viss frihet att antingen syssla med kritiskt granskande av källor eller att inte göra det. Samtidigt så innebär frånvaron av detaljstyrning att det saknas ramar för bedömning av kritisk källgranskning och användning av källor, något som kan leda till en viss en osäkerhet hos lärarna:"att räkna antal referenser är inte ett bra mått, men hur ska jag pröva förmågan?” (N2). När N3 resonerar kring hur förmågan ska bedömas framkommer ett aktivt bortval"det är ett begränsat antal moment i var text som jag väljer att fokusera på när jag ger respons, så då står till exempel inte källkritik på mitt responsschema då, där står det innehåll, struktur och språk”. Ju närmare examen i årskurs tre kommer desto större vikt lägger lärarna på att träna eleverna att använda referenser i skrivuppgifter då "det är mera explicit givet i bedömningsguiden" (N5). En lärare som har varit sensor för examen säger: "Ja, jag har ju varit sensor i några år, och då är det viktigt att de uppger sina källor, och så är det ett plus om de klarar att referera på ett bra vis i texten, så är det ett plus, men det avgör 
inte hela betyget" (N1). Skillnaden mot den svenska kontexten blir i det här sista yttrandet slående. Där avgörs faktiskt betyget vid nationella prov just på grundval av ifall elever uppger källor eller ej.

De två temana Mål i fokus och Ämnet i fokus beskriver lärarnas respons på citaten från läroplanerna men också hur de genom hela intervjuerna förhållit sig till sina respektive styrdokument och de utmaningar de upplever i mötet med elever när styrdokumentens intentioner ska realiseras i en undervisningspraktik.

\section{Diskussion}

Vi fann att villkoren för gymnasieskola i Sverige och Norge hos de intervjuade lärarna främjade två olika typer av hållningar till kritiskt granskande av källor; den ena (representerad i det svenska temat Målen i fokus) gav en mera mekanisk, kvantitativ utvärdering av källor - det Kim \& Hannafin (2016) beskriver som en inre utvärdering av källinformation. Den innebär att läsaren inte uppehåller sig vid mera djupgående frågeställningar som vad som rättfärdigar de argument som finns i dokument eller hur argumenten har genererats. Den andra hållningen (representerad i det norska temat Ämnet i fokus) gav en reflekterande inställning till vem som är avsändaren av en text och vilket (till exempel skönlitterärt) perspektiv den är skriven inom, men utan att fästa stor uppmärksamhet vid den information som kan utvinnas genom att noga granska källinformation. Läsaren engagerar sig alltså inte i den form av utvärdering som Kim \& Hannafin (2016) benämner som en yttre utvärdering av källinformation. Utifrån svaren som lärarna givit framstår det som att vare sig de svenska eller norska eleverna ges stöd $i$ att konstruera integrerade mentala modeller eller intertext modeller när de läser (Britt \& Rouet, 2012). Temat Målen i fokus visar att betygskriterier får verkan i undervisningen, samtidigt så blir undervisningen mera inriktad på att uppfylla en kvantitet - läraren ska kunna identifiera källor och se tydliga källhänvisningar. Det finns få exempel i intervjumaterialet i temat Målen i fokus på beskrivningar av aktiviteter där lärare talar om vikten av att värdera källinformation vid läsning av flera dokument, som till exempel vid online-läsning (Leu et al., 2015) eller där lässtrategin att använda källinformationen om ett dokument för att förutsäga, tolka och värdera ett innehåll förekommer. Lärarna stannar vid att diskutera med eleverna om vilka källor som är trovärdiga och hur eleverna ska lära sig att identifiera och välja trovärdiga källor, en mera ytlig utvärdering av källor (Britt \& Aglinskas, 2002; Kim \& Hannafin, 2016). När väl ett dokument är valt så verkar det som om reflektionen över vem avsändaren är avtar, istället för att låta reflektionen fördjupa läsningen eller bidra till att integrera information över flera dokument $i$ enlighet med The Documents Model (Britt \& Rouet, 2012).

På ett vis är det fördelaktigt att betygskriterierna i svensk gymnasieskola tydligt pekar ut vad som förväntas av lärare och elever eftersom lärarna i intervjuerna uppger att de ägnar tid åt att diskutera hur elever ska utvärdera sina sökträffar på Internet och vad de kan lita på. På ett annat vis, eftersom de Nationella proven tydligt anger 


\section{E. W. Brante and E. S. Lund}

att källanvisningar ska finnas med i elevtexterna för att eleverna ska bli godkända, så verkar det finnas en slagsida mot att pricka av att källanvisningar finns. Varken lärarens eller elevens huvudfokus blir att tolka och läsa information med hjälp av källinformationen, utan att säkra att det finns referenser i elevtexterna. De intervjuade lärarnas svar visar att betygskriterier och kriterierna för betyg på de nationella proven leder till att deras undervisning vrids mot referenshantering i text samt att välja "bra" källor, istället för mot en mera kritisk utvärdering av källinformation. Det finns därmed lägre förutsättningar för att en integration av källinformation och dokumentets innehåll sker, det som enligt Britt och Rouet (2012) kan leda till att läsare i större utsträckning förmår att konstruera mentala modeller över det de läser och fördjupar sin läsförståelse.

I temat Ämnet i fokus så framhålls reflekterande läsning. Den mesta läsning som de norska lärarna talar om rör skönlitterär läsning och här framkommer att lärarna skiljer på verk och författare. Det vill säga, de vill att orden och texten ska tala, inte författaren. Det sättet att se på litteraturanalys faller inom paradigmet The new criticism (Ransom, 1941; Wellek \& Warren, 1977), vilket framhåller närläsning och sätter texten i sig i centrum (Bertens, 2014). Det leder till att lärarna i lägre grad poängterar källinformation; dels upplever de den som irrelevant vid skönlitterär läsning, dels går en sådan läsart inte ut på att utvärdera informationens trovärdighet utan mera på att få en litterär upplevelse. Trots det framhåller lärarna att de vill att eleverna ska förstå att all skriven text har en avsändare. Att kritiskt granska text ligger i ämnets natur, menar de. Intentionerna att eleverna ska inta en kritisk granskande hållning gentemot text ger en reflekterande läsning, men av de norska lärarnas svar på intervjufrågorna framkommer att de i liten grad undervisar eleverna i hur de praktiskt ska gå tillväga för att utvärdera information. Möjligen är det ett resultat av de mera holistiska betygskriterier som finns i den norska läroplanen.

Ett urval på 18 lärare gör att resultaten inte är generaliserbara, utan bör ses som en beskrivning av just dessa lärares uppfattningar i de frågor de fick ställda till sig. Studien belyser dessutom endast lärare som var intresserade av att bidra med reflektioner runt temat. En svaghet i studien utgörs av att lärarna blev presenterade för olika citat (från de olika läroplanerna). Vi försökte att finna citat som var likvärdiga och hade liknande innebörd för att minska på skillnaderna, trots att läroplanerna ser olika ut och har olika sätt att skriva fram riktlinjer. Oansett våra ansträngningar är vi medvetna om att citaten har olika karaktär och kan i sig leda till olika typer av svar. Ett sätt att kompensera det var att i resten av intervjuerna strikt hålla oss till samma frågor, vilka var av mera generell karaktär.

Trots frågornas generella karaktär så valde de norska lärararna att i större utsträckning tala om kritisk läsning av skönlitterära texter och de svenska om sakprosatexter. Den skillnad mellan nationerna angående vilken typ av texter som det företrädesvis relaterades till ser vi som ett uttryck för vilket fokus dessa lärare har $i$ sin undervisning. Skillnaden i fokus kan eventuellt förklaras med olikheter i diskurs, skolkultur, lärarutbildning eller olikheter i styrdokumenten i andra delar än de vi 
har utgått från i intervjuerna. Skillnaden är på samma gång ett resultat och en begräsning i studien. Önskvärt hade varit att följa upp intervjuerna med nya intervjuer och explicit ställa frågor om olika typer av texter för att undersöka hur svaren då hade blivit. Vidare forskning kan belysa orsaken till skillnaden ytterligare. En ytterligare begränsning av studien är att alla frågor ställdes på svenska, något som kan ha varit mera krävande för de norska lärarna. Dock var det ingen som avböjde intervju av det skälet, och vid intervjutillfällena bedömdes förståelse som mycket god från både intervjuare och den intervjuade.

Trots begränsningar av studien så vill vi framhålla att våra resultat bidrar med information gällande lärares uppfattningar av de intentioner rörande kritiskt värdering av källinformation och kritiskt läsande som finns i respektive lands läroplaner. Vi menar, att det inte räcker med att tänka på om det är en bra källa eller ej och sen referera till den i en text; det räcker inte heller med att fundera på ords innebörd i en detaljerad närläsning - vad som måste till är att eleven kritiskt utvärderar källinformationen på flera nivåer (Kim \& Hannafin, 2016) genom hela läsningen av multipla dokument. Då ges förutsättningar för att eleven kan göra kopplingar mellan källinformation och innehåll, mellan innehåll och innehåll samt mellan källinformation och källinformation och på så vis förhoppningsvis nå fram till en integrerad mental modell över flera dokument (Britt \& Rouet, 2012). Då ges förutsättningar för att eleven börjar tänka på dokument som bestående av både innehåll och källinformation. Och, förhoppningsvis, då ges också bättre förutsättningar för att ungdomars literacy når det OECD (2013) menar är en väl utvecklad nivå av literacy - nämligen en förmåga att läsa kritiskt.

\section{Referenser}

Barzilai, S., Tzadok, E., \& Eshet-Alkalai,Y. (2015). Sourcing while reading divergent expert accounts: Pathways from views of knowing to written argumentation. Instructional Science, 43(6), 737-766.

Bertens, J.W. (2014). Literary theory: the basics. (3. ed.) London: Routledge.

Braasch, J. L., Bråten, I., Strømsø, H. I., Anmarkrud, Ø., \& Ferguson, L. E. (2013). Promoting secondary school students' evaluation of source features of multiple documents. Contemporary Educational Psychology, 38(3), 180-195.

Braun, V., \& Clarke, V. (2006). Using thematic analysis in psychology. Qualitative research in psychology, 3, $77-101$.

Britt, M. A., \& Aglinskas, C. (2002). Improving students' ability to identify and use source information. Cognition and Instruction, 20, 485-522. DOI: 10.1207/S1532690XCI2004_2

Britt, M. A., \& Rouet, J.-F. (2012). Learning with Multiple Documents: Component skills and their acquistion. I M. J. Lawson \& J. R. Kirby (Red.), Enhancing the Quality of Learning (ss. 276-314). New York: Cambridge University Press.

Britt, M. A., Rouet, J. F., \& Braasch, J. L. (2013). Documents as entities: Extending the situation model theory of comprehension. I M. A. Britt, S. R. Goldman \& J-F. Rouet (Red.), Reading: From words to multiple texts (ss.160-179). New York: Routledge.

Britt, M. A., Richter, T., \& Rouet, J. F. (2014). Scientific literacy: The role of goal-directed reading and evaluation in understanding scientific information. Educational Psychologist, 49(2), 104-122.

Bråten, I., Strømsø, H. I., \& Andreassen, R. (2016). Sourcing in professional education: Do text factors make any difference? Reading and Writing, 29, 1599. DOI: 10.1007/s11145-015-9611-y

Ericksson, G. \& Gustafsson, J-E.(2014). Bedömningens dubbla funktion - för lärande och likvärdighet. I U.P.Lundgren, R. Säljö \& C. Liberg (Red.) Lärande, skola, bildning: [grundbok för lärare] (ss. 559-594) . (3., [rev. och uppdaterade] utg.) Stockholm: Natur \& Kultur. 


\section{E. W. Brante and E. S. Lund}

Goldman, S. R., Braasch, J. L., Wiley, J., Graesser, A. C., \& Brodowinska, K. (2012). Comprehending and learning from Internet sources: Processing patterns of better and poorer learners. Reading Research Quarterly, 47, 356-381.

Goldman, S. R., Britt, M. A., Brown, W., Cribb, G., George, M., Greenleaf, C., ... \& Project READI. (2016). Disciplinary Literacies and Learning to Read for Understanding: A Conceptual Framework for Disciplinary Literacy. Educational Psychologist, 51, 219-246.

Hayes, N. (2000). Doing psychological research: gathering and analysing data. Buckingham, England: Open University Press.

Kammerer, Y., Meier, N., \& Stahl, E. (2016). Fostering secondary-school students' intertext model formation when reading a set of websites: The effectiveness of source prompts. Computers E Education, 102, 52-64.

Kiili, C., Laurinen, L., \& Marttunen, M. (2008). Students evaluating Internet sources: From versatile evaluators to uncritical readers. Fournal of Educational Computing Research, 39, 75-95.

Kim, S. M., \& Hannafin, M. J. (2016). Synergies: effects of source representation and goal instructions on evidence quality, reasoning, and conceptual integration during argumentation-driven inquiry. Instructional Science, 44, 441-476.

Kintsch, W. (1998). Comprehension: A paradigm for cognition. New York: Cambridge University Press.

Kress, G. (2014). Reading, learning, and 'texts' in their interaction with the digital media. NCRM Working Paper. N/A. (Unpublished)

Kvale, S., \& Brinkmann, S. (2015). Interviews: Learning the craft of qualitative research interviewing (3., [updated] ed.). Los Angeles: Sage Publications.

Leu, D. J., Everett-Cacopardo, H., Zawilinski, J., Mcverry, G., \& O'Byrne, W. I. (2013). New literacies of online reading comprehension. I C. Chapelle (Red.) The encyclopedia of applied linguistics. Chichester: Wiley-Blackwell.

Leu, D. J., Forzani, E., Rhoads, C., Maykel, C., Kennedy, C., \& Timbrell, N. (2015). The new literacies of online research and comprehension: Rethinking the reading achievement gap. Reading Research Quarterly, 50(1), 37-59.

Leu, D., Zawilinski, L., Forzani, E., \& Timbrell, N. (2015). I L. B. Gambrell \& L.M. Morrow (Red.) Best practices in literacy instruction (ss. 343-364). (Fifth edition.) New York: The Guilford Press.

Lindmark, T. (2013). Samhällskunskapslärares ämneskonceptioner. Diss. Umeå: Umeå Universitet, 2013, Umeå.

LK06. (2006). Lcereplanverket for Kunnskapsløftet. Hämtad från https://www.udir.no/laring-og-trivsel/ lareplanverket/

Mason, L., Junyent, A. A., \& Tornatora, M. C. (2014). Epistemic evaluation and comprehension of web-source information on controversial science-related topics: Effects of a short-term instructional intervention. Computers $\mathcal{E}$ Education, 76, 143-157. DOI: 10.1016/j.compedu.2014.03.016

OECD. (2013). Education at a Glance: OECD indicators. 2014. Hämtad från http://www.oecd.org/edu/Education-at-a-Glance-2014.pdf

Perfetti, C. A., Rouet, J.-F., \& Britt, M. A. (1999). Toward a theory of documentsrepresentation representation. I H. V. Oostendorp \& S. R. Goldman (Red.), The construction of mental representations during reading (ss. 88-108). Mahwah, N.J.:Erlbaum.

Ransom, J. C. (1941). The new criticism. New Directions.

Skolverket. (2015). Läroplan, examensmål och gymnasiegemensamma ämnen för gymnasieskolan 2011. Hämtad från www.skolverket.se/laroplaner-amnen-och-kurser.

Stang Lund, E., Bråten, I., Brante, E. W., \& Strømsø, H. I. (2017). Memory for textual conflicts predicts sourcing when asolescents read multiple expository texts. Reading Psychology, 38, 417-437.

Wellek, R., \& Warren, A. (1977). Theory of literature (3. [rev.] ed.). New York: Harcourt Brace Jovanovich.

Wiley, J., Goldman, S. R., Graesser, A. C., Sanchez, C. A., Ash, I. K., \& Hemmerich, J. A. (2009). Source evaluation, comprehension, and learning in Internet science inquiry tasks. American Educational Research Fournal, 46, 1060-1106. DOI: 10.3102/0002831209333183

Wineburg, S. S. (1991). Historical problem solving: A study of the cognitive processes used in the evaluation of documentary and pictorial evidence. Fournal of Educational Psychology, 83, 73. DOI: $10.1037 / 0022-0663.83 .1 .73$ 


\section{Appendix A}

\section{Citat som visades för svenska lärare som undervisar i svenska}

Från avsnittet Skolans värdegrund och uppgifter:

- Eleverna ska också kunna orientera sig i en komplex verklighet med stort informationsflöde och snabb förändringstakt. Deras förmåga att finna, tillägna sig och använda ny kunskap blir därför viktig. Eleverna ska träna sig att tänka kritiskt, att granska fakta och förhållande och att inse konsekvenserna av olika alternativ.

Från avsnitt Ämnets syfte (svenskämnet)

- Undervisningen ska även bidra till att eleverna utvecklar kunskaper om hur man söker, sammanställer och kritiskt granskar källor.

\section{Citat som visades för norska lärare som undervisar i norska:}

Från Grunnleggende ferdigheter - Digitale ferdigheter:

- ..i denne sammanhengen er det viktig å kunne vurdere og bruke kilder på en bevisst måte

Från Grunnleggende ferdigheter - $̊$ kunne lese

- Å kunne lese i norsk er å kunne finne informasjon og forstå resonnementer og framstillinger i ulike typer av tekster på skjerm og papir, og å kunne forholde sig kritisk og selvstendig til de leste tekstene. Utviklingen går fra grunnleggende avkoding og forståelse av enkle tekster til å kunne forstå, tolke, reflektere over og vurdere stadig mer komplekse tekster i ulike sjangere.

\section{Citat som visades för norsk lärare som undervisar i samhällskunskap:}

Från läroplan i samfunnsfag, hovudområda

- Å stimulere til kritisk vurdering av etablert og ny samfunnsfagleg kunnskap ved å bruke kjelder og kjeldekritikk er sentralt

Från Grunnleggende ferdigheter - $̊$ kunne lese

- Å kunne lese ... kunne behandle og bruke informasjon fra bilete, fil, teikningar, grafar, tabellar og kart og gjere målretta informasjonssøk, kritisk vurdering og medviten val og bortval av kjelder. 


\section{Appendix B}

Intervjufrågor

(Visar/läser citat)

Är det här något ni talar om? Hur har ni tänkt kring dessa frågor?

Hur realistiskt är det att eleverna når dit?

Hur kan andemeningen i de här citaten inlemmas i undervisningen?

Vilka utmaningar ser du med att arbeta med de här frågorna?

Kan du ge exempel på utmaningar som du har mött?

Kan du ge exempel på hur du övervann utmaningarna?

Kan du berätta om ett tillfälle då du undervisade om kritisk granskning av källor och/ eller kritisk läsning?

Vad gjorde du?

Hur gick det?

Vilka krav ställer du på att eleverna ska referera?

Vilken vikt lägger du vid referenshantering vid betygssättning?

Vilken är din uppfattning om varifrån elever hämtar material?

Hur skulle du vilja beskriva en kritisk och reflekterande läsare?

Vad upplever du som svårt för elever i relation till att kritiskt granska källor och läsa kritiskt?

Vilka misstag är vanliga att elever gör?

Är det någon speciell studentgrupp som du tycker har större problem än andra?

Hur definierar du kritisk källgranskning?

Vad tänker du avgör trovärdigheten hos en källa?

Grovt uppskattat, hur ofta undervisar du om kritisk källgranskning eller kritisk läsning?

Vad är det för mening med att lärare och elever lägger tid på att kritiskt granska källor? 